\title{
Mediating role of strategic orientations in the relationship between entrepreneurial orientation and performance of Saudi SMEs
}

\author{
Mohammed Abdulrab ${ }^{1}$ (D), Yaser Hasan S. Al-Mamary ${ }^{1}$ (D), Mohammed A. Alwaheeb ${ }^{1}$ (D), \\ Naif Ghazi M. Alshammari ${ }^{1}$ (D), Hamad Balhareth ${ }^{1}$ (D), Serhan A. Al-Shammari ${ }^{1}$ \\ 'University of Ha'il, Department of Management and Information Systems, College of Business Administration, Ha'il, Saudi \\ Arabia
}

How to cite: Abdulrab, M., Al-Mamary, Y.H.S., Alwaheeb, M.A. et al. (2021), “Mediating role of strategic orientations in the relationship between entrepreneurial orientation and performance of Saudi SMEs", Brazilian Journal of Operations \& Production Management, Vol. 18, No. 04, e20211113.

https://doi.org/10.14488/BJOPM.2021.029

\begin{abstract}
Goal: This study aims to examine the mediating role of strategic orientations in the relationship between entrepreneurial orientation and performance of small and medium enterprises (SMEs) in Saudi Arabia.

Design / Methodology / Approach: Quantitative analysis techniques is used in this study. Data from 206 KSA owners / managers of SMEs is obtained and analysed using Partial Least Squares Structural Equation Modelling (PLS-SEM).

Results: Findings indicate that strategic orientations mediate the relationship between entrepreneurial orientation and performance of SMEs in Saudi Arabia.

Limitations of the investigation: The proposed model may not be generalised and must be applied in other contexts and cultures.

Practical implications: This study indicates that KSA managers should maintain emphasis on entrepreneurship and establish unique strategic techniques to improve efficiency. Policymakers are recommended to establish entrepreneurship initiatives for SMEs to form entrepreneurship. Additional recommendations are also provided.

Originality / Value: This study adds to the current body of knowledge by addressing the mediating role of market and technology orientation in the relationship between entrepreneurial orientation and performance of Saudi SMEs.
\end{abstract}

Keywords: Entrepreneurial Orientation; Strategic Orientations; Performance; SMEs, KSA.

\section{INTRODUCTION}

According to the World Bank (2020), small and medium-sized enterprises (SMEs) are mandated to be productive and to pursue creative and proactive techniques towards analytical thought in the current complex market climate. SMEs account for approximately $90 \%$ of firms worldwide and $99.41 \%$ of the Saudi Arabia private sector (Monshaat, 2020). Particularly in advanced countries, SMEs are regarded as the key drivers of competition, fuelling jobs and promoting financial growth (Ndubisi et al., 2020). SME strategies play a critical role in advancing the corporate mission, maintaining vision and establishing the competitive advantages of a

Financial support: This research has been funded by Scientific Research Deanship at University of Ha'il- Saudi Arabia through project number RG-191349.

Conflict of interest: The authors have no conflict of interest to declare.

Corresponding author: yaser_almamary@yahoo.com

Received: 23 November 2020

Accepted: 03 March 2021

Editor: Julio Vieira Neto. 
company (Jardioui et al., 2019). These businesses do not need to devote massive marketing budgets or pursue large resources to gain competition. Even so, effective methods need to be implemented to meet higher objectives for greater performance. SMEs must implement innovative initiatives leading to potential advantages when existing strategies are obsolete (Liñán et al., 2019). SMEs should be able to challenge conventional management styles in developed countries and pursue efforts to convert these into constructive, highly successful and value-added strategy. In the Saudi context, SMEs need to implement solutions that generate value-added technologies for consumers and companies (Alrubaishi \& Robson, 2019).

In this strategy, orientation is one of the most critical aspects. Previous research demonstrated the value of entrepreneurial, market and technological orientations to boost efficiency in SMEs (Alnawas \& Farha, 2020). Corporations have to pursue a competitive strategy that can anticipate and respond to external developments in their market climate. In practice, strategic advice cause repercussions for SMEs by creating new and creative perspectives into their sector (Rizan et al., 2019). At present, the crucial position that entrepreneurial orientation plays in creativity, positive action and risk taking for SMEs is recognised. Entrepreneurial orientation helps grow a given organisation's competitive advantage, increases innovation performance (Ferreira et al., 2020) and encourages organisational reaction speed and corporate agility (Kohtamäki et al., 2020). In addition, strategy plays a significant impact on economic development and in organisational growth (Alhakimi \& Mahmoud, 2020).

The influence of entrepreneurial, market and technology orientations on SME efficiency in developing economies have been studied over the last two decades (Jogaratnam, 2017; Martin \& Javalgi, 2016, Abdulrab et al., 2020). Although this area has attracted extensive research, few studies have investigated the mediating effect of entrepreneurial orientation between strategic orientation and SMEs (Ali et al., 2020). Consequently, these gaps will be resolved in addition to the absence of earlier research on the effects of entrepreneurial, market and technology orientations on the performance of Saudi SMEs. The current research attempts to investigate the mediating role of strategic orientations in the relationship between entrepreneurial orientation and performance of Saudi SMEs.

\section{LITERATURE REVIEW AND HYPOTHESES DEVELOPMENT}

\subsection{Entrepreneurial orientation (EO)}

Entrepreneurial orientation is an attractive research issue, especially regarding the business output (Covin \& Wales, 2019, Al-Mamary et al., 2020a, Al-Mamary et al., 2020b). Execution, procedures and decision-making exercises are described to provide a guide for new and emerging enterprises (Rauch et al., 2009). Entrepreneurial orientation is a central factor in improving an organisation's strategic advantages (Covin \& Miles, 1999) and can improve efficiency in creativity (Zhai et al., 2018). Companies with a sound entrepreneurial orientation are superior to companies who neglect such strategy (Bouncken et al., 2016).

Miller (1983) defined entrepreneurial orientation as a measure that businesses use to introduce, take risks, predict and spotlight entrepreneurship. A growing number of scholars have followed this view as a merging of creativity, proactivity and risk-taking, with possible additions. Lumpkin and Dess (1996), for instance, interpreted entrepreneurial orientation from another point of view and found this definition to be a mixture of five dimensions, including those from Miller (1983) and Covin and Slevin (1989), competition and autonomy. Innovativeness is an attempt to use imagination and to encourage innovative ideas, inventions and creative moves, leading to new technologies, companies and high-tech procedures (Tidd and Bessant, 2018).

Risk-taking refers to the propensity of SMEs to take striking moves, such as the expansion of new unexplored markets or allocation of large organisational capital to tasks with dishonest consequences or strong borrowing (Dess \& Lumpkin, 2005). On the one hand, company owners and managers must determine the considerable opportunities to take because the 
vast amount of risks can adversely affect overall organisational successes, entrepreneurial advancement or creativity; on the other hand, low risk-taking willingness and low propensity for complexity in cultures of high uncertainty-avoidance (Ozaralli \& Rivenburgh, 2016). Proactiveness is also a significant contributor to the success of SMEs (Kreiser \& Davis, 2010).

\subsubsection{Entrepreneurial orientation and SMEs performance}

Entrepreneurial orientation is a crucial factor in organisational success. Employing the entrepreneurial orientation-quantification (Cho and Lee, 2018; Singh et al., 2019), Semrau et al. (2016) used a sample of 1.248 SMEs from different countries. The results illustrated that entrepreneurial orientation has a significant relation to the success of SMEs and is a common principle of importance and legality in various businesses and settings. Covin and Wales (2019) also examined the effect of entrepreneurial orientation on the different outcomes of SMEs, proving the correctness and relevance of its definition and calculation. Other studies demonstrated the impact on non-financial and financial affairs on the five axis of the multidimensional entrepreneurial orientation system on SMEs (e.g. creativity, pro-activeness, risk taking, autonomy and competitive aggression) (Hernández-Perlines et al., 2020).

As indicated by Centobelli et al. (2019), innovativeness is a key indicator for the financial and non-financial success of SMEs. Further, risk-taking is important in improving the organisational efficiency (Jung et al., 2020), as proven for SMEs (Astrini et al., 2020; Games, 2019). Pro-activeness improves financial efficiency (Hossain \& Al Asheq, 2019) and has an important influence on SMEs (Jalali et al., 2013). Proactive companies gain a strategic edge through customer demands, innovative campaigns and higher charges (Anwar and Shah, 2020). Mahar and Ghumro (2019) indicated that competitive aggressiveness and autonomy are important for the organisational successes of SMEs. Experiments have shown that entrepreneurial orientation influences the performance of SMEs (Khanagha et al., 2017; Lumpkin \& Dess, 1996), and consequently, the following hypothesis is suggested:

H1. Entrepreneurial orientation has a significant positive effect on Saudi SMEs performance.

\subsection{Strategic orientation (SO)}

Strategic orientation has been described as the execution of business operations behaviour of enterprises. The following hypothesis is that strategic orientation is important in assessing organisational success or failure. This principle has an effect on the management of SMEs. As a controllable element, strategic orientation can also enhance the overall SME efficiency. In addition, marketing analysis has shown that strategic orientation is a crucial driver for outstanding achievement in the developed world (liang, Mavondo and Zhao, 2019). Strategic orientation emphasises how corporations need to collaborate with external influences such as rivals, consumers and technologies (Asghari and Amani, 2016). Strategic orientation is connected with the competitive preferences, practices and actions of a business, and with the achievement of a sustained advantage and overall performance enhancement (Grinstein, 2008; Laukkanen et al., 2013).

Literature has studied and excessively discussed market and technology orientations as important strategic recommendations (Ardito and Dangelico, 2018). Kohli and Jaworski (1990) defined market orientation as the organisation's business intelligence generation of existing and upcoming needs, intelligence distribution across sections, and responsiveness. Three dimensions of market orientation are proposed: market intelligence that refers to the data obtained by an organisation about a particular sector or market; intelligence distribution that is essential for business-oriented strategy preparation; and responsiveness that refers to the capability that help businesses respond rapidly to growing market demands. In addition, Narver and Slater (1990) described market orientation as the productive and successful organisational culture, which generates the requisite action to achieve a higher consumer value and thus a continuous excellent market results.' Market orientation is thus manifested in three components: customer orientation, competitor orientation and inter-functional 
component. Businesses can reach full market orientation potential if they are guided by entrepreneurial orientation (Slater and Narver, 1995). Matsuno et al. (2002) found that entrepreneurial orientation drives business orientation; the higher the degree of entrepreneurial orientation, the higher the level of market orientation. This can be demonstrated by the fact that entrepreneurial orientation encourages the potential and desire of the company to understand the need to minimise ambiguity, contribute to business learning practices and to take more measured risks.

Technology orientation is a primary source for corporate growth and market advancement in various business forms (Masa'deh et al., 2018). Gatignon and Xuereb (1997) have described technology orientation as being able and committed to obtaining and using considerable technical experience in innovative technologies. Lei et al. (2019) also described technology orientation as the company ability to suggest or incorporate new technology, products or inventions. This description implies that the importance of consumers and longterm enterprise performance rely on the introduction of innovative technical solutions, goods, facilities or procedures (Kumar et al., 2018). A technology-based business strives to create new goods or services by acquiring the newest innovations. Technology orientation thereby contributes to financial and non-financial performance (Masa'deh et al., 2018).

The use of the most current technologies decide the technological strategy of an organisation, particularly as its technical resources and skills are gathered and dispersed. Furthermore, the growth, development and implementation of technologies are essential to the advancement of SMEs. Technology in low-tech businesses is mainly based on the implementation and advancement of technical innovation, but is a significant determinant for potential success in high-tech companies (Enjolras et al., 2019). Efficiency levels of SMEs using the same technology may also differ according to the implementation techniques applied given its initial introduction (Ruiz-Jiménez and del Mar Fuentes-Fuentes, 2016). A favourable association suggests that entrepreneurial orientation has a clear positive effect (Hakala, 2011) and a significant correlation with technology orientation. Moreover, Baker and Sinkula (2009) states a close connection between entrepreneurial and market orientations, and a correlation between entrepreneurial orientation and SMEs performance. Therefore, Matsuno et al. (2002) concluded that the market orientation exists particularly at the level of corporate culture. As such, the impact of entrepreneurial orientation on marketing and technology orientations may also be illustrated by the improved results of SMEs.

Based on the above discussion, the following hypotheses are proposed:

$\mathrm{H} 2$ : Entrepreneurial orientation has a significant positive effect on market orientation.

H3: Entrepreneurial orientation has a significant positive effect on technology orientation.

\subsubsection{Strategic orientation and SMEs performance}

Management strategy conceptualisation is commonly connected to achievement performance (Morgan and Strong, 2003). The positive linkage between strategic orientation and SMEs performance is well established in literature (Alani et al., 2019; Boohene, 2018; Espino-Rodríguez and Ramírez-Fierro, 2018; Lin et al., 2019; Obeidat, 2016; Omar et al., 2019). A market-oriented approach facilitates and strengthens strong efficiency, provided that consumer expectations and loyalty are prioritised (Reijonen et al., 2012). Market orientation enhances the performance of manufacturing corporations (Alhakimi and Mahmoud, 2020; Ali et al., 2020; Narver and Slater, 1990). SME managers are thus inspired to use market orientation to satisfy evolving consumer expectations and concurrently accomplish market objectives (Masa'deh et al., 2018; Tidd and Bessant, 2018). Current research also shows the relation between market orientation and SMEs (Ali et al., 2020; Amin et al., 2016; Isichei et al., 2020), but requires further analysis for its exploration. The correlation between technology orientation and the performance of SMEs was also examined (Adegbuyi et al., 2018; Hsu et al., 2014; Rajala and Westerlund, 2012).

Therefore, the following hypotheses are proposed:

H4: Market orientation has a significant positive effect on SMEs performance. 
H5: Technology orientation has a significant positive effect on SMEs performance.

H6: Market orientation has a mediation effect in the relationship between entrepreneurial orientation and SMEs performance.

H7: Technology orientation has a mediation effect in the relationship between entrepreneurial orientation and SMEs performance.

Figure 1 shows the following research model based on the above rationale.

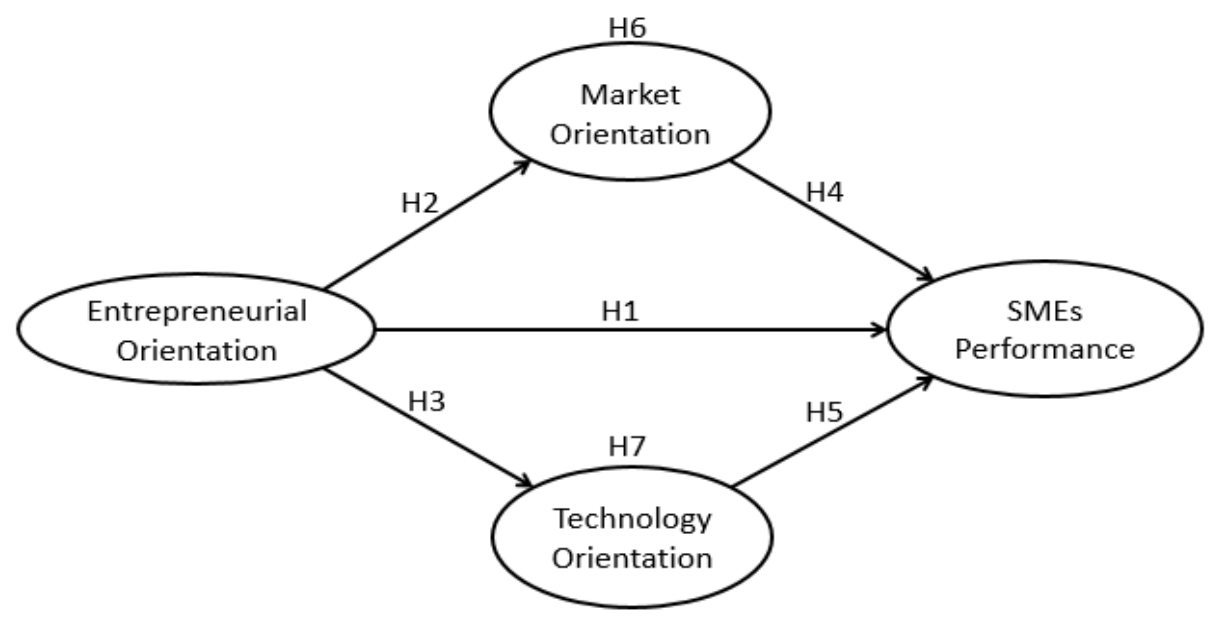

Figure 1: The research framework

\section{RESEARCH METHODOLOGY}

Quantitative approach is used to gather information on the mediating role of strategic orientation in the relationship between entrepreneurial orientation and performance of SMEs. This study uses a survey questionnaire, which was less boring and available regardless of location. Partial Least Squares Structural Equation Modelling (PLS-SEM) using Smart PLS software is applied to examine the research hypotheses (Ramayah et al., 2018). Likert-style scales are used to measure all indicators. Entrepreneurial orientation is measured using a 9-item scale, which includes three dimensions adopted from Covin and Slevin (1989). Market orientation is measured using a 15-item scale that comprises three dimensions adopted from Narver and Slater (1990). A sample item is 'Our competitive advantage is based on understanding customers' needs.' Furthermore, technology orientation is measured using a 12-item scale adopted from Gatignon and Xuereb (1997). Moreover, the performance of SMEs is measured using 10 items adopted from Anwar and Shah (2020) and Danso et al. (2016). The efficiency of SMEs is measured relative to their main competitors or industry over the last three years ( $1=$ 'extremely declining'; $5=$ 'extremely improved'). An online survey is shared through social networks including email groups, Twitter and WhatsApp to owners and managers of Saudi SMEs. Google Forms are used to gather details, and the Arabic questionnaire is requested to be completed by the respondents. Data collection took approximately two months in 2020. The online survey yields a total of 230 participants, and after deletion of incomplete answers, the final dataset contained 206 participants.

\section{STATISTICAL ANALYSIS AND RESULTS}

\subsection{Measurement model assessment}

As recommended by Ringle et al. (2020), this study considered measurement model reliability and validity and used composite reliability and Cronbach's alpha to evaluate internal consistency of a measurement item. According to Hair Junior et al. (2017), the value of Cronbach's alpha should be 0.7 or higher. Similarly, the appropriate composite reliability value 
for the construct should be 0.7 or above. Table 1 reveals that all constructs in this study attained a minimum value of 0.7 for composite reliability and Cronbach's alpha, suggesting adequate internal reliability.

Table 1. Loading, Cronbach's alpha, Composite Reliability and AVE.

\begin{tabular}{|c|c|c|c|c|c|}
\hline Constructs & Indicators & Loading & $\begin{array}{l}\text { Cronbach's } \\
\text { alpha }\end{array}$ & $\begin{array}{l}\text { Composite } \\
\text { Reliability }\end{array}$ & $\begin{array}{l}\text { Average } \\
\text { Variance } \\
\text { Extracted }\end{array}$ \\
\hline \multirow{9}{*}{$\begin{array}{c}\text { Entrepreneurial } \\
\text { Orientation }\end{array}$} & Inn1 & 0.846 & 0.806 & 0.885 & 0.720 \\
\hline & $\operatorname{lnn} 2$ & 0.851 & & & \\
\hline & Inn3 & 0.849 & & & \\
\hline & Pro1 & 0.880 & 0.837 & 0.902 & 0.755 \\
\hline & Pro2 & 0.888 & & & \\
\hline & Pro3 & 0.837 & & & \\
\hline & Rit1 & 0.910 & 0.844 & 0.906 & 0.764 \\
\hline & Rit2 & 0.902 & & & \\
\hline & Rit3 & 0.805 & & & \\
\hline \multirow{15}{*}{ Market Orientation } & Cuo1 & 0.868 & 0.937 & 0.950 & 0.761 \\
\hline & Cuo2 & 0.853 & & & \\
\hline & Cuo3 & 0.911 & & & \\
\hline & Cuo4 & 0.882 & & & \\
\hline & Cuo5 & 0.894 & & & \\
\hline & Cuo6 & 0.826 & & & \\
\hline & Com1 & 0.913 & 0.932 & 0.952 & 0.831 \\
\hline & Com2 & 0.932 & & & \\
\hline & Com3 & 0.954 & & & \\
\hline & Com4 & 0.844 & & & \\
\hline & Inc1 & 0.785 & 0.827 & 0.878 & 0.591 \\
\hline & Inc2 & 0.762 & & & \\
\hline & Inc3 & 0.780 & & & \\
\hline & Inc4 & 0.715 & & & \\
\hline & Inc5 & 0.799 & & & \\
\hline \multirow{12}{*}{$\begin{array}{l}\text { Technology } \\
\text { Orientation }\end{array}$} & TO1 & 0.790 & \multirow{12}{*}{0.960} & \multirow{12}{*}{0.965} & \multirow{12}{*}{0.697} \\
\hline & TO2 & 0.882 & & & \\
\hline & TO3 & 0.782 & & & \\
\hline & TO4 & 0.852 & & & \\
\hline & TO5 & 0.880 & & & \\
\hline & TO6 & 0.798 & & & \\
\hline & TO7 & 0.774 & & & \\
\hline & TO8 & 0.819 & & & \\
\hline & TO9 & 0.850 & & & \\
\hline & T010 & 0.915 & & & \\
\hline & T011 & 0.901 & & & \\
\hline & T012 & 0.761 & & & \\
\hline \multirow{10}{*}{ Performance } & Perf1 & 0.814 & \multirow{10}{*}{0.949} & \multirow{10}{*}{0.956} & \multirow{10}{*}{0.687} \\
\hline & Perf2 & 0.725 & & & \\
\hline & Perf3 & 0.751 & & & \\
\hline & Perf4 & 0.823 & & & \\
\hline & Perf5 & 0.910 & & & \\
\hline & Perf 6 & 0.898 & & & \\
\hline & Perf7 & 0.854 & & & \\
\hline & Perf8 & 0.759 & & & \\
\hline & Perf9 & 0.882 & & & \\
\hline & Perf10 & 0.851 & & & \\
\hline
\end{tabular}


Hair Junior et al. (2017) also suggested the investigation of discriminant and convergent validity. Convergent validity could be evaluated using other indicators, including the load factor and average variance extracted (AVE). All indicators attained values of loading above 0.7 , which is appropriate in multivariate analysis (Hair Junior et al., 2014). AVE values ranged 0.591-0.831 and were greater than 0.5 nominal value (Fornell \& Larcker, 1981). Two tests for discriminant validity were administered, namely, the heterotrait-monotrait test (HTMT), to assess the discriminant value of constructs (Henseler et al., 2015). The values of the HTMT relation should be less than 0.85 to show discriminant validity. The results showed that all values were below the 0.85 criterion, indicating proper discriminatory validity (Henseler et al., 2015). On the basis of such analyses, PLS-SEM predictions were considered verified by the dataset.

\subsection{Structural model assessment}

The bootstrap method is used to evaluate the structural model (Chin, 2010). Following the determination of the measurement model, the assessment was carried out to confirm the hypotheses. Path coefficients and R2 values for accessing a structural model are used in PLSSEM. Figure 2 and Table 2 indicate the verification of the five direct hypotheses. Entrepreneurial orientation shows significant impact on performance of SMEs $(\beta=0.370$, $t=2.600, p<0.05$ ), Thus, $\mathrm{H} 1$ is accepted. Likewise, entrepreneurial orientation shows a significant effect on market orientation $(\beta=0.856, t=27.789, p<0.05)$ and technology orientation ( $\beta=0.544, t=9.510, p<0.05)$. Thus, $\mathrm{H} 2$ and $\mathrm{H} 3$ are accepted. Furthermore, market orientation shows a significant influence on performance of SMEs $(\beta=0.308, t=2.042$, $p<0.05)$. Thus, $\mathrm{H} 4$ is accepted. Technology orientation also shows a significant effect on the performance of SMEs $(\beta=0.211, t=3.009, p<0.05)$. Thus, H5 is accepted. Moreover, the bootstrapping method is used to validate the mediating effect investigated in the present study. This method has been used and suggested for research that evaluates these indirect effects (Hayes, 2009). Based on the results in Table 3, entrepreneurial orientation has significant indirect effect on the performance of SMEs through market orientation $(\beta=0.264$, $t=2.055, p<0.05)$. Similarly, technology orientation has a significant role in mediating the relationship between entrepreneurial orientation and SMEs performance $(\beta=0.115, t=2.772$, $p<0.05)$. Acceptable $\mathrm{R}^{2}$ standards vary; nevertheless, the $\mathrm{R} 2$ value proposed by Chin (1998) is 0.60 and higher as substantial, (0.33-0.59) as moderate and (0.19-0.32) as weak. Figure 2 indicates that all independent variables clarify $64.9 \%$ of the performance variance.

Table 2. Structural model: direct effect

\begin{tabular}{cccccc}
\hline Hypothesis & Relationship & Std. Beta & t-value & p-value & Decision \\
\hline H1 & EO -> Perf & 0.370 & 2.600 & 0.010 & Supported \\
H2 & EO -> MO & 0.856 & 27.789 & 0.000 & Supported \\
H3 & EO -> TO & 0.544 & 9.510 & 0.000 & Supported \\
\hline H4 & MO -> Perf & 0.308 & 2.042 & 0.042 & Supported \\
\hline H5 & TO -> Perf & 0.211 & 3.009 & 0.003 & Supported \\
\hline
\end{tabular}

Table 3. Structural model: mediation analysis

\begin{tabular}{cccccc}
\hline Hypothesis & Relationship & Std. Beta & t-value & p-value & Decision \\
\hline H1 & EO -> MO -> Perf & 0.264 & 2.055 & 0.040 & Supported \\
\hline H2 & EO -> TO -> Perf & 0.115 & 2.772 & 0.006 & Supported \\
\hline
\end{tabular}




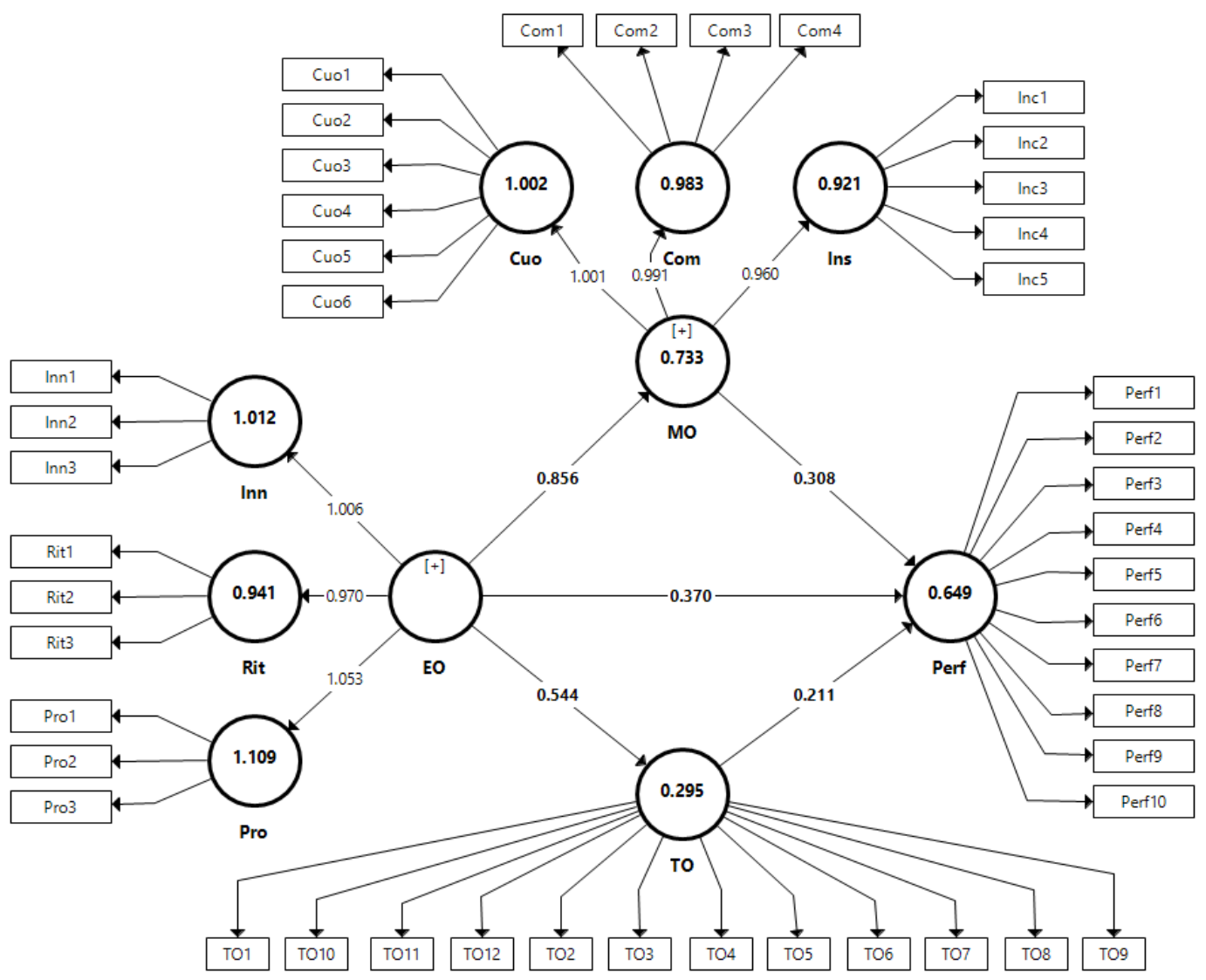

Figure 2: Path coefficient results

\section{DISCUSSIONS AND CONCLUSION}

This research investigates the mediating role of strategic orientation in the relationship between entrepreneurial orientation and performance of Saudi SMEs. Entrepreneurial orientation is hypothesised to have a positive impact on the performance of SMEs, which the results reveal to be significant $(\beta=0.370, t=2.600, p<0.05)$. This result is consistent with previous research, which found that performance is significantly affected by entrepreneurial orientation (e.g., Jalali et al., 2013; Ali et al., 2020). Previous studies claimed that entrepreneurial orientation represents the degree to which an organisation can adjust risktaking and proactive tactics to creativity (Covin and Slevin, 1989). Thus, organisations with high entrepreneurial orientation tend to be able to perform better than those with limited concerns. The implementation of entrepreneurial orientation strategy in SMEs contributes to the innovation and the creation of innovative goods, services and technical processes in a more competitive environment (Ramezan et al., 2013).

Similarly, entrepreneurial orientation exhibits a significant effect on market orientation $(\beta=0.856, t=27.789, p<0.05)$ and technology orientation $(\beta=0.544, t=9.510, p<0.05)$. This finding broadly supports previous studies that showed entrepreneurial orientation has a significant influence on market orientation (Matsuno et al., 2002; Slater and Narver, 1995) and positive effect on or significant correlation with technology orientation (Hakala, 2011; Wiklund and Shepherd, 2005).

The impact of market orientation on SME efficiency is also discussed. Market orientation significantly affects SME performance $(\beta=0.308, t=2.042, p<0.05)$, verifying the results of several studies (e.g., Al-Henzab et al., 2018; Lekmat et al., 2018; and Alhakimi and Mahmoud, 2020). As a component of strategic orientations, market orientation may affect the performance of Saudi SMEs. Market orientation may also include guidelines for actions related to the creation of and responsiveness to business knowledge (Amin et al., 2016). By cultivating interest in the knowledge of consumers and rivals, market-based companies can effectively 
adapt and respond to evolving consumer demands by providing new goods and services (Ali et al., 2020). Technology orientation also exhibits a significant effect on the performance of SMEs $(\beta=0.211, t=3.009, p<0.05)$, supporting the results of Hsu et al. (2014) and Lei et al. (2019). Therefore, technology orientation may encourage risk-taking, create innovative ideas that shape consumer behaviour and contribute to the growth of developing markets (Ali et al., 2020). The present findings are consistent with earlier literature (Adegbuyi et al., 2018; Ali et al., 2016) that indicates technology orientation has a significant effect on the performance of SMEs. Technology orientation has often been viewed as optimistic, with its capacity to strengthen the use of digital technologies in the mixed marketing elements (e.g. commodity, price, delivery and promotions) (Adams et al., 2019).

Furthermore, the results reveal that market orientation mediates the relationships between entrepreneurial orientation and the performance of Saudi SMEs $(\beta=0.264, t=2.055$, $p<0.05)$. This research illustrates the indirect effect of entrepreneurial orientation on the performance of SMEs as mediated by market orientation, and highlights the role of entrepreneurial orientation in the performance of SMEs. The results are consistent with previous papers (Baker and Sinkula, 2009; Kohli and Jaworski, 1990; Slater and Narver, 1995) and clarified that in the relationship between entrepreneurial orientation and SME efficiency, market orientation plays a mediating role. For example, Matsuno et al. (2002) demonstrated that market orientation fully mediates the relationship between entrepreneurial orientation and company efficiency, and that companies that already have a high entrepreneurial orientation should similarly cultivate market orientation. As a result, the characteristics of market orientation require the inter-functional orientation in the organisation to satisfy market demands, and the ability to consider the view of rivals in an environment of economic competition, which is vital for SMEs to increase their performance. Likewise, the results revealed that technology orientation mediates the relationships between entrepreneurial orientation and performance of Saudi SMEs $(\beta=0.115, t=2.772, p<0.05)$. This finding is consistent with the results of Hakala and Kohtamäki (2010). However, this finding contradicts a related study by Shim and Seo (2019), who found that technology orientation did not significantly mediate the relationship between entrepreneurial orientation and the performance of Saudi SMEs.

In brief, this analysis reveals a significant relationship between entrepreneurial orientation and the performance of SMEs. In addition, market and technology orientations mediate the relationships between entrepreneurial orientation and the performance of Saudi SMEs. While this study focuses on current literature, previous findings have been discussed in various environments and contexts. Therefore, this study helps to recognise the value of introducing various strategic directions, which can increase the efficiency of Saudi SMEs.

\section{IMPLICATIONS AND FUTURE RESEARCH}

This study investigates the mediating role of strategic orientations in the relationship between entrepreneurial orientation and the performance of Saudi SMEs. This study adds to the current body of knowledge by addressing the mediating role of market and technology orientations in the relationship between entrepreneurial orientation and the performance of Saudi SMEs. The results can be used as a guide for management to measure the performance and use of different strategic orientations that can maximise the efficiency of SMEs. In addition, to enhance their efficiency, Saudi SMEs need to concentrate on several strategic orientations. The methods in which these strategic orientations lead to the success of SMEs must also be considered by owners and managers. Their success must be assessed in terms of performance metrics and then how these factors apply to each other must be considered. Evaluating various facets of the performance of SMEs can assist management in evaluating successes and developing strategies. This study shows that the integration of several orientations is an ideal approach for improving the performance of SMEs. These findings reflect the findings of Masa'deh et al. (2018), who also found that relying on only one strategic orientation can lead to poor performance of SMEs. In view of the lack of resources relevant to 
the budget, SMEs face difficulties in aligning time and expertise with various strategic orientations. Managers must then first evaluate their current position to explain future directions and then establish suitable procedures. Generally, these results reinforce guidelines for introducing technology orientation with visionary qualities and market-oriented practices that can enhance the efficiency of SMEs.

While the goals of this study are well accomplished, certain limitations remain to be discussed. Numerous recommendations for future studies also require mention. First, this study analyses only the combined impact of entrepreneurial, market and technology orientations on the performance of SMEs in Saudi Arabia. Future studies must also explore other variables that can affect the performance of SMEs, and the mediating role of other factors. Moreover, this study only uses the expectations of SME owners and managers to assess their performance, which may have had an effect on the metrics. Future studies are also urged to concentrate on measures of objective performance. Consequently, this study uses a cross-sectional design in which the data are obtained at one point in time. Future studies should also conduct a longitudinal study to explore the impact of entrepreneurial orientation on performance of Saudi SMEs, and the mediating role of strategic orientations in such relationship.

\section{REFERENCES}

Abdulrab, M., Alwaheeb, M.A., Al-Mamary, Y.H. et al. (2020), “Effect of entrepreneurial orientation and strategic orientations on financial and nonfinancial performance of small and medium enterprises in Saudi Arabia", Journal of Public Affairs, Vol. $\cdots$, pp. 2305.

Adams, P., Freitas, I.M.B. and Fontana, R. (2019), "Strategic orientation, innovation performance and the moderating influence of marketing management", Journal of Business Research, Vol. 97, pp. 129-40. http://dx.doi.org/10.1016/j.jbusres.2018.12.071.

Adegbuyi, A.A., Oladele, O.P., lyiola, O.O. et al. (2018). An empirical review of technology orientation and small and medium enterprises (SMEs) performance. in Proceedings of the $32^{\text {nd }}$ International Business Information Management Association Conference, IBIMA 2018 - Vision 2020: Sustainable Economic Development and Application of Innovation Management from Regional expansion to Global Growth.

Al-Henzab, J., Tarhini, A. and Obeidat, B.Y. (2018), "The associations among market orientation, technology orientation, entrepreneurial orientation and organizational performance", Benchmarking, Vol. 25, pp. 3117-3142.

Alani, E., Kamarudin, S., Alrubaiee, L. et al. (2019), "A model of the relationship between strategic orientation and product innovation under the mediating effect of customer knowledge management", Journal of International Studies, Vol. 12, No. 3, pp. 232-42. http://dx.doi.org/10.14254/2071-8330.2019/12-3/19.

Alhakimi, W. and Mahmoud, M. (2020), "The impact of market orientation on innovativeness: evidence from Yemeni SMEs", Asia Pacific Journal of Innovation and Entrepreneurship, Vol. 14, No. 1, pp. 47-59.

Ali, D., Leifu, G. and Rehman, R.-u. (2016), “The impact of technology orientation and Customer orientation on firm Performance: evidence form chinese firms", International Journal of Management and Marketing Research, Vol. 9, No. 1, pp. 1-11.

Ali, G.A., Hilman, H. and Gorondutse, A.H. (2020), "Effect of entrepreneurial orientation, market orientation and total quality management on performance Evidence from Saudi SMEs", Benchmarking, Vol. 27, No. 4, pp. 1503-31. http://dx.doi.org/10.1108/BIJ-08-2019-0391.

Al-Mamary, Y.H.S., Abdulrab, M., Alwaheeb, M.A. et al. (2020a), "Factors impacting entrepreneurial intentions among university students in Saudi Arabia: testing an integrated model of TPB and EO", Education + Training, Vol. 62, No. 7/8, pp. 779-803. http://dx.doi.org/10.1108/ET-04-2020-0096.

Al-Mamary, Y.H., Alwaheeb, M.A., Alshammari, N.G.M. et al. (2020b), "The effect of entrepreneurial orientation on financial and non-financial performance in Saudi SMES: a review", Journal of Critical Reviews, Vol. 7, No. 14, pp. 270-8.

Alnawas, I. and Farha, A.A. (2020), "Strategic orientations and capabilities' effect on SMEs' performance", Marketing Intelligence \& Planning, Vol. 38, No. 7, pp. 829-45. http://dx.doi.org/10.1108/MIP-11-20190548. 
Alrubaishi, D. and Robson, P. (2019), "Innovation in Saudi Family SMEs: The role of social capital and family involvement", International Review of Entrepreneurship, Vol. 17, No. 1

Amin, M., Thurasamy, R., Aldakhil, A.M. et al. (2016), "The effect of market orientation as a mediating variable in the relationship between entrepreneurial orientation and SMEs performance", Nankai Business Review International, Vol. 7, No. 1, pp. 39-59. http://dx.doi.org/10.1108/NBRI-08-2015-0019.

Anwar, M. and Shah, S.Z.A. (2020), “Entrepreneurial orientation and generic competitive strategies for emerging SMEs: Financial and nonfinancial performance perspective", Journal of Public Affairs. http://dx.doi.org/10.1002/pa.2125.

Ardito, L. and Dangelico, R.M. (2018), "Firm environmental performance under scrutiny: The role of strategic and organizational orientations", Corporate Social Responsibility and Environmental Management, Vol. 25, No. 4, pp. 426-40. http://dx.doi.org/10.1002/csr.1470.

Asghari, A.F. and Amani, R. (2016), "Surveying the Influence of Market and Innovation Orientation on ELoyalty (Case Study: an Iranian Company). Journal of Administrative Management", Education + Training, Vol. 12, No. 4, pp. 43-50.

Astrini, N., Rakhmawati, T., Sumaedi, S. et al. (2020). “Innovativeness, Proactiveness, and Risk-taking: Corporate Entrepreneurship of Indonesian SMES' In IOP Conference Series: Materials Science and Engineering. http://dx.doi.org/10.1088/1757-899X/722/1/012037.

Baker, W.E. and Sinkula, J.M. (2009), "The complementary effects of market orientation and entrepreneurial orientation on profitability in small businesses", Journal of Small Business Management, Vol. 47, No. 4, pp. 443-64. http://dx.doi.org/10.1111/j.1540-627X.2009.00278.x.

Boohene, R. (2018). Entrepreneurial orientation, strategic orientation and performance of small family firms in the Kumasi Metropolis. Academy of Entrepreneurship Journal.

Bouncken, R.B., Plüschke, B.D., Pesch, R. et al. (2016), “Entrepreneurial orientation in vertical alliances: joint product innovation and learning from allies", Review of Managerial Science, Vol. 10, No. 2, pp. 381 409. http://dx.doi.org/10.1007/s11846-014-0150-8.

Centobelli, P., Cerchione, R. and Singh, R. (2019), "The impact of leanness and innovativeness on environmental and financial performance: Insights from Indian SMEs", International Journal of Production Economics, Vol. 212, pp. 111-24. http://dx.doi.org/10.1016/j.ijpe.2019.02.011.

Chin, W. W. (1998), "Commentary: Issues and opinion on structural equation modeling" MIS Quarterly, Vol. 22, No. 1, pp. 7-16.

Chin, W.W. (2010), How to write up and report PLS analyses Handbook of partial least squares. Springer, Berlin, Heidelberg, pp. 655-690. http://dx.doi.org/10.1007/978-3-540-32827-8_29.

Cho, Y.H. and Lee, J.-H. (2018). Entrepreneurial orientation, entrepreneurial education and performance. Asia Pacific Journal of Innovation and Entrepreneurship, Vol. 12, No. 2, pp. 124-34. http://dx.doi.org/10.1108/APJIE-05-2018-0028.

Covin, J.G. and Miles, M.P. (1999), "Corporate entrepreneurship and the pursuit of competitive advantage", Entrepreneurship Theory and Practice, Vol. 23, No. 3, pp. 47-63. http://dx.doi.org/10.1177/104225879902300304.

Covin, J.G. and Slevin, D.P. (1989), "Strategic management of small firms in hostile and benign environments", Strategic Management Journal, Vol. 10, No. 1, pp. 75-87. http://dx.doi.org/10.1002/smj.4250100107.

Covin, J.G. and Wales, W.J. (2019). Crafting high-impact entrepreneurial orientation research: Some suggested guidelines. Los Angeles, CA, SAGE Publications Sage.

Danso, A., Adomako, S., Damoah, J.O. et al. (2016), “Risk-taking propensity, managerial network ties and firm performance in an emerging economy", The Journal of Entrepreneurship, Vol. 25, No. 2, pp. 15583. http://dx.doi.org/10.1177/0971355716650367.

Dess, G.G. and Lumpkin, G.T. (2005), "The role of entrepreneurial orientation in stimulating effective corporate entrepreneurship", The Academy of Management Perspectives, Vol. 19, No. 1, pp. 147-56. http://dx.doi.org/10.5465/ame.2005.15841975.

Enjolras, M., Camargo, M., \& Schmitt, C. (2019), "Are High-Tech Companies More Competitive Than Others? An Empirical Study of Innovative and Exporting French SMEs", Technology Innovation Management Review, Vol. 9, No 1. 
Espino-Rodríguez, T.F. and Ramírez-Fierro, J.C. (2018), “The relationship between strategic orientation dimensions and hotel outsourcing and its impact on organizational performance. An application in a tourism destination", Sustainability (Switzerland), Vol. 10, No. 6, pp. 1769. http://dx.doi.org/10.3390/su10061769.

Ferreira, J., Coelho, A. and Moutinho, L. (2020), “Dynamic capabilities, creativity and innovation capability and their impact on competitive advantage and firm performance: The moderating role of entrepreneurial orientation", Technovation, Vol. 92, pp. 102061. http://dx.doi.org/10.1016/j.technovation.2018.11.004.

Fornell, C. and Larcker, D.F. (1981), "Evaluating structural equation models with unobservable variables and measurement error", JMR, Journal of Marketing Research, Vol. 18, No. 1, pp. 39-50. http://dx.doi.org/10.1177/002224378101800104.

Games, D. (2019), "Can SME benefit from innovation in an emerging market economy", Academy of Entrepreneurship Journal, Vol. 25, No. 1, pp. 1-10.

Gatignon, H. and Xuereb, J.-M. (1997), "Strategic orientation of the firm and new product performance", JMR, Journal of Marketing Research, Vol. 34, No. 1, pp. 77-90. http://dx.doi.org/10.1177/002224379703400107.

Grinstein, A. (2008), "The relationships between market orientation and alternative strategic orientations",

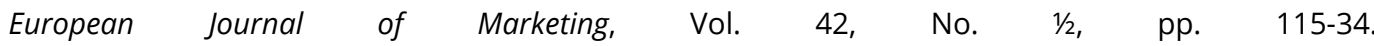
http://dx.doi.org/10.1108/03090560810840934.

Hair Junior, J.F., Sarstedt, M., Hopkins, L. et al. (2014), “Partial least squares structural equation modeling (PLS-SEM)", European Business Review

Hair Junior, J. F., Sarstedt, M., Ringle, C. M., \& Gudergan, S. P. (2017). Advanced issues in partial least squares structural equation modeling. SAGE publications, Thousand Oaks, CA.

Hakala, H. (2011), "Strategic orientations in management literature: Three approaches to understanding the interaction between market, technology, entrepreneurial and learning orientations", International Journal of Management Reviews, Vol. 13, No. 2, pp. 199-217. http://dx.doi.org/10.1111/j.14682370.2010.00292.x.

Hakala, H. and Kohtamäki, M. (2010), “The interplay between orientations: Entrepreneurial, technology and customer orientations in software companies", Journal of Enterprising Culture, Vol. 18, No. 03, pp. 265-90. http://dx.doi.org/10.1142/S0218495810000598.

Hayes, A.F. (2009), "Beyond Baron and Kenny: Statistical mediation analysis in the new millennium", Communication Monographs, Vol. 76, No. 4, pp. 408-20. http://dx.doi.org/10.1080/03637750903310360.

Henseler, J., Ringle, C.M. and Sarstedt, M. (2015), "A new criterion for assessing discriminant validity in variance-based structural equation modeling", Journal of the Academy of Marketing Science, Vol. 43, No. 1, pp. 115-35. http://dx.doi.org/10.1007/s11747-014-0403-8.

Hernández-Perlines, F., Ariza-Montes, A. and Araya-Castillo, L. (2020), "Socioemotional wealth, entrepreneurial orientation and international performance of family firms", Economic ResearchEkonomska Istraživanja, Vol. 33, No. 1, pp. 3125-45. http://dx.doi.org/10.1080/1331677X.2019.1685398.

Hossain, M.U. and Al Asheq, A. (2019), "The Role of Entrepreneurial Orientation to SME Performance in Bangladesh", International Journal of Entrepreneurship, Vol. 23, No. 1, pp. 1-6.

Hsu, T.T., Tsai, K.H., Hsieh, M.H., \& Wang, W. Y. (2014), "Strategic orientation and new product performance: the roles of technological capability", Canadian Journal of Administrative Sciences, Vol. 31, No. 1, pp. 44-58.

Isichei, E.E., Agbaeze, K.E. and Odiba, M.O. (2020), "Entrepreneurial orientation and performance in SMEs The mediating role of structural infrastructure capability", International Journal of Emerging Markets, Vol. 15, No. 6, pp. 1219-41. http://dx.doi.org/10.1108/IJOEM-08-2019-0671.

Jalali, A., Jaafar, M. and Thurasamy, R. (2013), "Influence of entrepreneurial orientation on the financial performance: evidence from SMEs in Iran", Middle East Journal of Management, Vol. 1, No. 2, pp. 16885. http://dx.doi.org/10.1504/MEJM.2013.057263.

Jardioui, M., Garengo, P. and El Alami, S. (2019), “How organizational culture influences performance measurement systems in SMEs", International Journal of Productivity and Performance Management, Vol. 69, No. 2, pp. 217-35. http://dx.doi.org/10.1108/IJPPM-10-2018-0363. 
Jiang, W., Mavondo, F. and Zhao, W. (2019), “The impact of business networks on dynamic capabilities and product innovation: The moderating role of strategic orientation", Asia Pacific Journal of Management, Vol. ‥, pp. 1-28. http://dx.doi.org/10.1007/s10490-018-9628-2.

Jogaratnam, G. (2017), “The effect of market orientation, entrepreneurial orientation and human capital on positional advantage: Evidence from the restaurant industry", International Journal of Hospitality Management, Vol. 60, No. 1, pp. 104-13. http://dx.doi.org/10.1016/j.ijhm.2016.10.002.

Jung, K.B., Kang, S.-W. and Choi, S.B. (2020), “Empowering Leadership, Risk-Taking Behavior, and Employees' Commitment to Organizational Change: The Mediated Moderating Role of Task Complexity", Sustainability, Vol. 12, No. 6, pp. 2340. http://dx.doi.org/10.3390/su12062340.

Khanagha, A., Dehkordi, A.M., Zali, M.R. et al. (2017), "Performance implications of entrepreneurial orientation at public research and technology institutions", Entrepreneurship and Sustainability Issues, Vol. 4, No. 4, pp. 601-10. http://dx.doi.org/10.9770/jesi.2017.4.4(15).

Kohli, A.K. and Jaworski, B.J. (1990), "Market orientation: the construct, research propositions, and managerial implications", Journal of Marketing, Vol. 54, No. 2, pp. 1-18. http://dx.doi.org/10.1177/002224299005400201.

Kohtamäki, M., Heimonen, J., Sjödin, D. et al. (2020), "Strategic agility in innovation: Unpacking the interaction between entrepreneurial orientation and absorptive capacity by using practice theory", Journal of Business Research, Vol. 118, pp. 12-25. http://dx.doi.org/10.1016/j.jbusres.2020.06.029.

Kreiser, P.M. and Davis, J. (2010), “Entrepreneurial orientation and firm performance: The unique impact of innovativeness, proactiveness, and risk-taking", Journal of Small Business and Entrepreneurship, Vol. 23, No. 1, pp. 39-51. http://dx.doi.org/10.1080/08276331.2010.10593472.

Kumar, U., Butt, I. and Kumar, V. (2018), "The impact of strategic orientations on development of manufacturing strategy and firm's performance", International Journal of Technology Management, Vol. 77, No. 4, pp. 187-209. http://dx.doi.org/10.1504/IJTM.2018.092954.

Laukkanen, T., Nagy, G., Hirvonen, S. et al. (2013), "The effect of strategic orientations on business performance in SMEs", International Marketing Review, Vol. 30, No. 6, pp. 510-35. http://dx.doi.org/10.1108/IMR-09-2011-0230.

Lei, L., Wu, X. and Fu, Y. (2019), "Effects of Sustainability and Technology Orientations on Firm Growth: Evidence from Chinese Manufacturing", Sustainability, Vol. 11, No. 16, pp. 4406. http://dx.doi.org/10.3390/su11164406.

Lekmat, L., Selvarajah, C. and Hewege, C. (2018), "Relationship between Market Orientation, Entrepreneurial Orientation, and Firm Performance in Thai SMEs: The Mediating Role of Marketing Capabilities", International Journal of Business \& Economics, Vol. 17, No. 3

Lin, Y., Luo, J., leromonachou, P. et al. (2019), "Strategic orientation of servitization in manufacturing firms and its impacts on firm performance", Industrial Management \& Data Systems, Vol. 119, No. 2, pp. 292 316. http://dx.doi.org/10.1108/IMDS-10-2017-0485.

Liñán, F., Paul, J. and Fayolle, A. (2019), "SMEs and entrepreneurship in the era of globalization: advances and theoretical approaches", Small Business Economics, Vol. 55, pp. 1-9.

Lumpkin, G.T. and Dess, G.G. (1996), "Clarifying the entrepreneurial orientation construct and linking it to performance", Academy of Management Review, Vol. 21, No. 1, pp. 135-72. http://dx.doi.org/10.5465/amr.1996.9602161568.

Mahar, S., and Ghumro, I. A. (2019). Entrepreneurial orientation its impact on business performance of small and medium enterprises of Sindh. SSRN Electronic Journal. Vol. V, No. I, pp. 458-68.

Martin, S.L. and Javalgi, R.R.G. (2016), “Entrepreneurial orientation, marketing capabilities and performance: the moderating role of competitive intensity on Latin American International new ventures", Journal of Business Research, Vol. 69, No. 6, pp. 2040-51. http://dx.doi.org/10.1016/j.jbusres.2015.10.149.

Masa'deh, R., Al-Henzab, J., Tarhini, A. et al. (2018), “The associations among market orientation, technology orientation, entrepreneurial orientation and organizational performance", Benchmarking, Vol. 25, No. 8, pp. 3117-42. http://dx.doi.org/10.1108/BIJ-02-2017-0024.

Matsuno, K., Mentzer, J.T. and Özsomer, A. (2002), "The effects of entrepreneurial proclivity and market orientation on business performance", Journal of Marketing, Vol. 66, No. 3, pp. 18-32. http://dx.doi.org/10.1509/jmkg.66.3.18.18507. 
Miller, D. (1983), "The correlates of entrepreneurship in three types of firms", Management Science, Vol. 29, No. 7, pp. 770-91. http://dx.doi.org/10.1287/mnsc.29.7.770.

Monshaat. (2020). The Impact of COVID-19 on SME in Saudi Arabia: A Large-Scale Survey. Riyadh, Saudi Arabia: Prince Sultan University, Saudi Economic Association.

Morgan, R.E. and Strong, C.A. (2003), "Business performance and dimensions of strategic orientation", Journal of Business Research, Vol. 56, No. 3, pp. 163-76. http://dx.doi.org/10.1016/S01482963(01)00218-1.

Narver, J.C. and Slater, S.F. (1990), "The effect of a market orientation on business profitability", Journal of Marketing, Vol. 54, No. 4, pp. 20-35. http://dx.doi.org/10.1177/002224299005400403.

Ndubisi, N.O., Zhai, X.A. and Lai, K. (2020), “Small and medium manufacturing enterprises and Asia's sustainable economic development", International Journal of Production Economics, Vol. 233, pp. 107971. http://dx.doi.org/10.1016/j.ijpe.2020.107971.

Obeidat, B.Y. (2016), "The effect of strategic orientation on organizational performance: The mediating role of innovation. International Journal of Communications", Network and System Sciences, Vol. 9, No. 11, pp. 478-505. http://dx.doi.org/10.4236/ijcns.2016.911039.

Omar, A.R.C., Hussin, M.Y.M. and Muhammad, F. (2019), "Assessing strategic orientation and mosques performance", Review of World Economics, Vol. 10, No. 5, pp. 30-5. http://dx.doi.org/10.5430/rwe.v10n5p30.

Ozaralli, N. and Rivenburgh, N.K. (2016), “Entrepreneurial intention: antecedents to entrepreneurial behavior in the USA and Turkey", Journal of Global Entrepreneurship Research, Vol. 6, No. 1, pp. 3. http://dx.doi.org/10.1186/s40497-016-0047-x.

Rajala, R. and Westerlund, M. (2012). The effects of service orientation, technology orientation and open innovation on the performance of software-intensive service businesses. In $45^{\text {th }}$ Hawaii International Conference on System Sciences. IEEE, Maui, HI. http://dx.doi.org/10.1109/HICSS.2012.563.

Ramayah, T., Cheah, J., Chuah, F. et al. (2018). Partial least squares structural equation modeling (PLS-SEM) using smartPLS 3.0 An Updated Guide and Practical Guide to Statistical Analysis. Pearson, Kuala Lumpur, Malaysia.

Ramezan, M., Sanjaghi, M.E. and Baly, H.R.K. (2013), “Organizational change capacity and organizational performance: An empirical analysis on an innovative industry", Journal of Knowledge-based Innovation in China, Vol. 5, No. 3, pp. 188-212. http://dx.doi.org/10.1108/JKIC-07-2013-0012.

Rauch, A., Wiklund, J., Lumpkin, G.T. et al. (2009), “Entrepreneurial orientation and business performance: An assessment of past research and suggestions for the future", Entrepreneurship Theory and Practice, Vol. 33, No. 3, pp. 761-87. http://dx.doi.org/10.1111/j.1540-6520.2009.00308.x.

Reijonen, H., Laukkanen, T., Komppula, R. et al. (2012), "Are growing SMEs more market-oriented and brand-oriented", Journal of Small Business Management, Vol. 50, No. 4, pp. 699-716. http://dx.doi.org/10.1111/j.1540-627X.2012.00372.x.

Ringle, C.M., Sarstedt, M., Mitchell, R. et al. (2020), "Partial least squares structural equation modeling in HRM research", International Journal of Human Resource Management, Vol. 31, No. 12, pp. 1617-43. http://dx.doi.org/10.1080/09585192.2017.1416655.

Rizan, M., Balfas, F. and Purwohedi, U. (2019), "The influence of strategic orientation, organizational innovation capabilities and strategic planning on the performance of technology-based firms", Academy of Strategic Management Journal, Vol. 18, No. 3, pp. 1-11.

Ruiz-Jiménez, J.M. and del Mar Fuentes-Fuentes, M. (2016), “Management capabilities, innovation, and gender diversity in the top management team: An empirical analysis in technology-based SMEs", $B R Q$ Business Research Quarterly, Vol. 19, No. 2, pp. 107-21. http://dx.doi.org/10.1016/j.brq.2015.08.003.

Semrau, T., Ambos, T. and Kraus, S. (2016), "Entrepreneurial orientation and SME performance across societal cultures: An international study", Journal of Business Research, Vol. 69, No. 5, pp. 1928-32. http://dx.doi.org/10.1016/j.jbusres.2015.10.082.

Shim, Y. and Seo, J. (2019), "A Study on Entrepreneurial Orientation and Startup Performance: Mediating Effect of Strategic Orientation", International Journal of Emerging Multidisciplinary Research, Vol. 3, No. 4, pp. 32-40.

Singh, S.H., Bhowmick, B., Eesley, D. et al. (2019), "Grassroots innovation and entrepreneurial success: Is entrepreneurial orientation a missing link", Technological Forecasting and Social Change, Vol. 164, pp. 119582. http://dx.doi.org/10.1016/j.techfore.2019.02.002. 
Slater, S.F. and Narver, J.C. (1995), "Market orientation and the learning organization”, Journal of Marketing, Vol. 59, No. 3, pp. 63-74. http://dx.doi.org/10.1177/002224299505900306.

Tidd, J. and Bessant, J.R. (2018). Managing innovation: integrating technological, market and organizational change. John Wiley \& Sons.

Wiklund, J. and Shepherd, D. (2005), “Entrepreneurial orientation and small business performance: a configurational approach", Journal of Business Venturing, Vol. 20, No. 1, pp. 71-91. http://dx.doi.org/10.1016/j.jbusvent.2004.01.001.

World Bank (2020), "Small and Medium Enterprises (SMES) Finance", available at: https://www.worldbank.org/en/topic/smefinance.

Zhai, Y.-M., Sun, W.-Q., Tsai, S.-B. et al. (2018), "An empirical study on entrepreneurial orientation, absorptive capacity, and SMEs' innovation performance: A sustainable perspective", Sustainability, Vol. 10, No. 2, pp. 314. http://dx.doi.org/10.3390/su10020314.

Author contributions: All authors contributed equally to this paper. 